\title{
Kedudukan Pejabat Sementara Notaris dalam Hal Notaris Diberhentikan Sementara dari Jabatannya
}

\author{
Komang Teja Pradnyana ${ }^{1}$, K Ketut Mertha ${ }^{2}$
}

${ }^{1}$ Kantor Notaris Ni Ketut Ardani, E-mail: tejapradnyana.9@gmail.com

2Fakultas Hukum Universitas Udayana, E-mail: ketut.mertha46@gmail.com

\begin{tabular}{l}
\hline Info Artikel \\
\hline Masuk : 29 April 2021 \\
Diterima : 23 Juni 2021 \\
Terbit : 1 Juli 2021 \\
Keywords : \\
Notary; Temporary Notary \\
Officer; Temporarily \\
suspended from his/her \\
position. \\
\\
\\
Korresponding Author: \\
Komang Teja Pradnyana, E- \\
mail: \\
tejapradnyana.9@gmail.com \\
DoI: \\
10.24843/AC.2021.v06.i02.p12 \\
Nata kunci: \\
Notaris; Pemberhentian \\
Sementara dari Jabatannya. \\
\end{tabular}

\begin{abstract}
The purpose of this writing is to determine the ratio legis for the position of Temporary Notary Officer in the event that the Notary is temporarily suspended from his/her position and to understand the reformulation of the regulation of the position of the Notary's Temporary Officer in the event that the Notary is temporarily suspended from his/her position. The research method used is the normative research method, which departs from the absence of norm on the regulation of the position of Temporary Notary Officer in order to carry out the position of a temporarily suspended Notary as stipulated in Article 1 point 2 of the UUJN-Amendment, with a statutory approach and a conceptual approach. The technique of collecting legal material is in the form of card system technique and legal material analysis technique in the form of descriptive technique and construction technique. The research findings are as follows: Ratio Legis for the position of a Notary's Temporary Officer in the event that a Notary is temporarily suspended from his/her position is to maintain the continuity of the Notary's position, even though the Notary (official) cannot carry out his/her duties for a while because of being temporarily suspended, but persist because it is a permanent work sector. Regulatory reformulation of the position of Temporary Notary Officer in the event that the Notary is temporarily suspended from office is by establishing a norm that revises the norm of Article 1 point 2 UUJNAmendment.
\end{abstract}


penelitian adalah sebagaiberikut: Ratiolegis kedudukan Pejabat Sementara Notaris dalam hal Notaris diberhentikan sementara dari jabatannya adalah untuk mempertahankan keberlangsungan jabatan Notaris itu sendiri, meskipun Notaris (pejabat) tidak dapat melaksanakan tugas jabatannya untuk sementara waktu karena diberhentikan sementara, namun jabatan Notaris harus tetap ada karena merupakan lingkungan pekerjaan tetap. Reformulasi pengaturan atas kedudukan Pejabat Sementara Notaris dalam hal Notaris diberhentikan sementara dari jabatannya adalah dengan pembentukan norma yang merevisi norma Pasal 1 angka 2 UUJN-Perubahan.

\section{Pendahuluan}

Prinsip negara hukum dianut oleh Indonesia yang diejawantahkan dalam konstitusinya. Hal ini tercermin dalam ketentuan Pasal 1 ayat (3) Undang-Undang Dasar Negara Republik Indonesia 1945 (selanjutnya disebut UUD NRI 1945) bahwa "Negara Indonesia adalah negara hukum." Norma tersebut berarti bahwa Indonesia menganut prinsip supremasi hukum, hukum berkedudukan sebagai anasir tertinggi dalam tata laksana berbangsa dan bernegara.

Hukum bertujuan menciptakan keadilan, kepastian, dan kemanfaatan. ${ }^{1}$ Salah satu aspek yang mendukung atas penciptaan tiga tujuan hukum tersebut adalah alat bukti. Alat bukti merupakan instrumen yang ditujukan guna menguatkan dan/atau membantah dalil-dalil yang dikemukakan atas suatu peristiwa hukum dan/atau perbuatan hukum. Salah satu jenis alat bukti yang diakui keberadaanya dalam Hukum Acara Perdata adalah bukti tulisan, yang terdiri atas tulisan autentik dan tulisan di bawah tangan. ${ }^{2}$ Tulisan autentik sebagaimana dimaksud adalah akta autentik. Dalam bidang keperdataan akta autentik adalah alat bukti yang memiliki daya bukti sempurna dalam arti mempunyai kekuatan pembuktian yang penuh, hal tersebut tidak dimiliki oleh akta di bawah tangan. ${ }^{3}$

Akta autentik merupakan produk hukum dari pejabat umum yang berwenang. Notaris merupakan salah satu pejabat umum yang dimaksud selain pula terdapat pejabat umum lainnya yang memiliki kewenangan dalam hal pembuatan akta autentik, diantaranya Pejabat Pembuat Akta Tanah, Pejabat Pembuat Akta Ikrar Wakaf, dan Pejabat Lelang. Pasal 1 angka 1 Undang-Undang Nomor 2 Tahun 2014 Tentang Perubahan atas Undang-Undang Nomor 30 Tahun 2004 Tentang Jabatan Notaris (selanjutnya disebut UUJN-Perubahan) menentukan bahwa "Notaris adalah pejabat umum yang berwenang untuk membuat akta autentik dan memiliki kewenangan lainnya sebagaimana dimaksud dalam undang-undang ini atau berdasarkan undang-undang lainnya."

\footnotetext{
1 Sagama, S. (2016). Analisis Konsep Keadilan, Kepastian Hukum dan Kemanfaatan dalam Pengelolaan Lingkungan. Mazahib, 15(1), 20-41, h.22, DOI: 10.21093/mj.v15i1.590

2 Momuat, O. M. (2014). Alat Bukti Tulisan Dalam Pemeriksaan Perkara Perdata Di Pengadilan. Lex Privatum, 2(1). 134-143, h.138.

3 Pramono, D. (2015). Kekuatan Pembuktian Akta Yang Dibuat Oleh Notaris Selaku Pejabat Umum Menurut Hukum Acara Perdata Di Indonesia. Lex Jurnalica, 12(3), 248-258, h.253.
} 
Kedudukan Notaris dalam kualifikasinya sebagai pejabat umum menjelaskan bahwa kewenangan yang terdapat dalam jabatan Notaris merupakan kewenangan asli yang berasal dari undang-undang (dalam hal ini adalah UUJN-Perubahan) yang diberikan berdasarkan atribusi, kewenangan tersebut bukan merupakan irisan kewenangan pada jabatan lainnya. Kewenangan utama Notaris yakni membuat akta autentik, sepanjang pembuatan akta-akta autentik untuk jenis akta-akta tertentu tidak diberikan kepada pejabat lainnya berdasarkan atribusi, delegasi, maupun mandat, maka pembuatan akta tersebut merupakan kewenangan Notaris. ${ }^{4}$

Pembuatan akta autentik oleh atau di hadapan Notaris didasari keinginan/kehendak para pihak guna kemudian diformulasikan dalam akta. Hal tersebut berlaku dengan pembatasan-pembatasan sebagai berikut:

1. Tidak terdapat perkecualian atas pembuatan akta-akta untuk jenis tertentu yang menjadi kewenangan pejabat umum lain yang ditetapkan berdasarkan peraturan perundang-undangan;

2. Mengenai pihak-pihak yang berkaitan dengan akta, dalam arti subjek hukum yang diperbolehkan menurut ketentuan peraturan perundangundangan. ${ }^{5}$

Di sisi lain kewenangan Notaris juga meliputi tindakan-tindakan hukum tertentu di luar pembuatan akta autentik. Hal tersebut berdasarkan Pasal 15 ayat (2) UUJNPerubahan, yakni:

"1. Mengesahkan tanda tangan dan menetapkan kepastian tanggal surat di bawah tangan dengan mendaftar dalam buku khusus;

2. Membukukan surat-surat di bawah tangan dengan mendaftar dalam buku khusus;

3. Membuat kopi dari asli surat-surat di bawah tangan berupa salinan yang membuat uraian sebagaimana ditulis dan digambarkan dalam surat yang bersangkutan;

4. Melakukan pengesahan kecocokan fotokopi dengan surat aslinya;

5. Memberikan penyuluhan hukum sehubungan dengan perbuatan akta;

6. Membuat akta yang berkaitan dengan pertananahan;

7. Membuat akta risalah lelang."

Terdapat pula kewenangan Notaris lainnya yang diatur dalam peraturan perundangundangan. Hal tersebut ditentukan dalam Pasal 15 ayat (3) UUJN-Perubahan, bahwa "Selain kewenangan sebagaimana dimaksud pada ayat (1) dan ayat (2), Notaris mempunyai kewenangan lain yang diatur dalam peraturan perundang-undangan." Adapun maksud ketentuan tersebut yakni "kewenangan lain yang diatur dalam peraturan perundang-undangan, antara lain, kewenangan mensertifikasi transaksi yang dilakukan secara elektronik (cyber notary), membuat Akta ikrar wakaf, dan hipotek pesawat terbang."

${ }^{4}$ Erwinsyahbana, T. (2018). Kewenangan dan Tanggung Jawab Notaris Pengganti setelah Pelaksanaan Tugas dan Jabatan Berakhir. Lentera Hukum, 5(2), 323-340, h.324, DOI: 10.19184/ejlh.v5i2.7339

5 Adjie, H. (2018). Hukum Notaris Indonesia (Tafsir Tematik Terhadap UU No. 30 Tahun 2004 Tentang Jabatan Notaris). Bandung: Refika Aditama. h.40 
Pada dasarnya kewenangan merupakan kekuasaan yang sah berdasarkan aturan hukum yang berlaku. Begitu juga halnya dengan Notaris, tindakan-tindakan hukum yang dilakukan olehnya berdasarkan kewenangannya adalah sah dan legal sedangkan tindakan-tindakan yang dilakukan di luar kewenangannya menjadikan tindakan tersebut tidak memiliki kekuatan dan tidak terdapat peluang untuk dilaksanakan (non executable). Oleh karenanya dalam hal terdapat kerugian bagi pihak atau para pihak yang diakibatkan dari tindakan Notaris di luar kewenangannya itu, maka yang bersangkutan dapat menggugat perdata maupun menuntut pidana terhadap Notaris. 6

Dalam hal terdapat permasalahan hukum yang disebabkan oleh tindakan di luar kewenangan yang dilakukan Notaris, maka Notaris itu dapat dimintai pertanggungjawabannya melalui pengenaan sanksi terhadapnya. Dalam keseluruhan materi muatan UUJN jo. UUJN-Perubahan diatur dua jenis sanksi, yakni sanksi perdata dan sanksi administratif. Sanksi perdata disebabkan oleh penurunan kualitas pembuktian akta Notaris yang semula memiliki daya bukti yang sempurna kemudian menjadi daya bukti seperti akta di bawah tangan atau disebut juga dengan degradasi kekuatan pembuktian. Hal ini dapat menjadi dasar bagi pihak atau para pihak yang dirugikan menuntut Notaris untuk mengganti rugi, biaya dan bunga dengan jumlah tertentu sesuai dengan kerugian tersebut. Sanksi administratif merupakan sanksi/hukuman (punishment) yang dikenakan oleh pejabat yang memiliki kewenangan untuk itu terhadap Notaris dalam bentuk tindakan administrarif tertentu meliputi peringatan lisan, peringatan tertulis, pemberhentian Notaris dari jabatannya baik untuk jangka waktu tertentu, dengan hormat, atau dengan tidak hormat.

Khusus mengenai sanksi administratif dalam bentuk pemberhentian Notaris dari jabatannya untuk jangka waktu tertentu atau dalam terminologi yang digunakan dalam UUJN-Perubahan yakni pemberhentian sementara, diatur dalam Pasal 9 UUJNPerubahan, sebagai berikut:

“(1) Notaris diberhentikan sementara dari jabatannya karena:

a. dalam proses pailit atau penundaan kewajiban pembayaran utang;

b. berada di bawah pengampuan;

c. melakukan perbuatan tercela;

d. melakukan pelanggaran terhadap kewajiban dan larangan jabatan serta kode etik Notaris; atau

e. sedang menjalin masa penahanan.

(2) Sebelum pemberhentian sementara sebagaimana dimaksud pada ayat (1) dilakukan, Notaris diberi kesempatan untuk membela diri di hadapan Majelis Pengawasan secara berjenjang.

(3) Pemberhentian sementara Notaris sebagaimana dimaksud pada ayat (2) dilakukan oleh Menteri atas usul Majelis Pengawas Pusat.

(4) Pemberhentian sementara berdasarkan alasan sebagaimana dimaksud pada ayat (1) huruf c dan huruf d berlaku paling lama 6 (enam) bulan."

Dalam hal Notaris diberhentikan untuk jangka waktu tertentu (sementara) dari jabatannya oleh Menteri Hukum dan Hak Asasi Manusia atas rekomendasi Majelis Pengawas Pusat, maka Majelis Pengawas Pusat merekomendasikan Pejabat Sementara

${ }^{6}$ Ibid, h.82 
Notaris kepada Menteri. Hal ini berdasarkan Pasal 80 ayat (1) UUJN, bahwa: "Selama Notaris diberhentikan sementra dari jabatannya, Majelis Pengawas Pusat mengusulkan seorang Pejabat Sementara Notaris kepada Menteri." Adapun yang dimaksud dengan Pejabat Sementara Notaris ditentukan dalam Pasal 1 angka 2 UUJNPerubahan, sebagai berikut: "Pejabat Sementara Notaris adalah seorang yang untuk sementara menjabat sebagai Notaris untuk menjalankan jabatan dari Notaris yang meninggal dunia."

Merujuk ketentuan-ketentuan sebagaimana dimaksud di atas, tampak bahwa terdapat kekosongan norma (leemten van normen) dalam redaksi Pasal 1 angka 2 UUJNPerubahan, bahwa Pejabat Sementara Notaris hanya ditujukan guna melaksanakan jabatan Notaris secara sementara bagi Notaris yang meninggal dunia, dan bukan bagi yang diberhentikan sementara. Oleh karenanya diperlukan pembentukan norma baru guna mengisi kekosongan norma tersebut yang berkedudukan sebagai hukum yang dicita-citakan (ius constituendum).

Beranjak pada uraian tersebut di atas, rumusah masalah dalam penelitian ini adalah sebagai berikut: Apa ratio legis kedudukan Pejabat Sementara Notaris dalam hal Notaris diberhentikan sementara dari jabatannya? Bagaimana reformulasi pengaturan atas kedudukan Pejabat Sementara Notaris dalam hal Notaris diberhentikan sementara dari jabatannya?. Terkait dengan rumusan masalah tersebut di atas adapun tujuan penulisan ini diantaranya (1) Mengetahui ratio legis kedudukan Pejabat Sementara Notaris dalam hal Notaris diberhentikan sementara dari jabatannya; dan (2) Memahami reformulasi pengaturan atas kedudukan Pejabat Sementara Notaris dalam hal Notaris diberhentikan sementara dari jabatannya.

Hasil penelusaran penelitian guna menyelidiki perbandingan dengan tulisan terdahulu yang memiliki kemiripan dengan tulisan ini menunjukkan tidak adanya penelitian lain yang meneliti masalah yang sama. Atas hal tersebut, berikut ini akan diuraikan beberapa karya tulis terdahulu yang memiliki kemiripan dengan penelitan ini, diantaranya:

“Winny Kartika Tantri, F.X. Arsin Lukman, Henny Marlyna, 2020, Jurnal Indonesian Notary, dengan judul Kewenangan Pejabat Sementara Notaris yang Membuat Akta Pertanahan Tidak dalam Kewenangannya Sebagai PPAT, menggunakan metode penelitian yuridis normatif, dengan rumusan masalah (1) Bagaimana batasan antara kewenangan Pejabat Sementara Notaris dengan kewenangan PPAT? dan (2) Bagaimana tanggung jawab Pejabat Sementara Notaris dalam membuat akta PPAT terhadap akta pertanahan yang dibuatnya? Hasil penelitian menunjukkan (1) Pejabat Sementara Notaris yang sedang menjalankan jabatan tidak dapat serta merta membuat akta pertanahan, dirinya harus memiliki dasar surat penunjukan dari BPN dan serah terima protokol PPAT, sehingga jika Pejabat Sementara Notaris melakukan kesahalan harus bertanggung jawab atas kesalahannya. (2) Jika terdapat pihak-pihak yang menuntut ganti kerugian, maka Pejabat Sementara Notaris harus bertanggung jawab secara perdata dan harus mendapatkan sanksi administratif sesuai UUJN dan Kode Etik Notaris."7

7 Tantri,W.K. (2020). Kewenangan PejabatSementara Notaris yang Membuat Akta Pertanahan Tidak dalam Kewenangannya Sebagai PPAT. Indonesian Notary, 2(4), 696-716, h.696-716. 
"Ni Nyoman Candra Krisnayanti, Ida Ayu Putu Widiati, Ni Gusti Ketut Sri Astiti, 2020, Jurnal Interpratasi Hukum, dengan judul Tanggung Jawab Notaris Pengganti dalam Hal Notaris yang Diganti Meninggal Dunia Sebelum Cuti Berakhir, menggunakan metode penelitian hukum normatif, dengan rumusan masalah (1) Bagaimana status hukum Notaris Pengganti dalam hal Notaris yang diganti meninggal dunia sebelum cuti berakhir? dan (2) Bagaimana mekanisme penyelesaian administrasi protokol Notaris Pengganti apabila Notaris yang diganti meninggal dunia sebelum cuti berakhir? Hasil penelitian menunjukkan (1) Status hukum Notaris Pengganti akan menggantikan posisi jabatan dari Notaris yang cuti sementara, sakit atau bahkan meninggal dunia. Notaris Pengganti akan melakukan dan menjalankan segala tugas dari Notaris yang digantikan dengan sementara ataupun seterusnya. Pada saat itu Notaris Pengganti tidak perlu dilantik lagi berdasarkan ketentuan Pasal 35 ayat 3 UUJN-P. (2) Dalam waktu paling tidak 60 hari sejak meninggalnya Notaris yang digantikan tersebut, Notaris Pengganti harus menyiapkan segala protokol dan membuat berita acara penyerahan protokol, lalu semua protokol tersebut diberikan kepada Notaris yang menerima protokol. Jika protokol tersebut sudah diserahkan, maka kemudian akan ditandatangani oleh seorang Notaris Pengganti, Notaris yang menerima protokol, dan Majelis Pengawas Daerah setempat sebagai Pejabat Sementara Notaris." 8

Merujuk pada hasil penelusuran penelitian tersebut terdapat perbedaan substansial antara penelitian ini dengan penelitian-penelitian terdahulu yang disebutkan di atas. Penelitan ini berfokus pada kedudukan Pejabat Sementara Notaris dalam hal Notaris diberhentikan sementara dari jabatannya yang beranjak dari kekosongan norma Pasal 1 angka 2 UUJN-Perubahan, sedangkan penelitian-penelitian terdahulu tersebut berfokus pada kewenangan Pejabat Sementara Notaris dalam pembuatan akta pertanahan dan tanggung jawab Notaris Pengganti yang karena jabatannya menjabat sebagai Pejabat Sementara Notaris guna menjalankan jabatan Notaris yang meninggal dunia pada saat cuti.

Terkait dengan uraian di atas, penelitian ini ditujukan guna pengembangan ilmu hukum khususnya bidang kenotariatan melalui pemahaman atas keadaan normatif kekosongan norma dalam Pasal 1 angka 2 UUJN-Perubahan berikut solusi yang ditawarkan melalui pembentukan norma guna mengisi kekosongan norma tersebut. Di sisi lain, penelitian ini ditujukan sebagai tambahan referensi bagi Notaris maupun Pejabat Sementara Notaris terkait dengan kedudukan Pejabat Sementara Notaris dalam hal Notaris diberhentikan sementara dari jabatannya.

\section{Metode Penelitian}

Penelitian adalah usaha pencarian guna pengembagan keilmuan dan teknologi dengan teknik penemuan kebenaran ilmiah. Peter Mahmud Marzuki mengemukakan

8 Krisnayanti, N. N. C., Widiati, I. A. P., \& Astiti, N. G. K. S. (2020). Tanggung Jawab Notaris Pengganti dalam Hal Notarisyang Diganti Meninggal Dunia Sebelum Cuti Berakhir. Jurnal Interpratasi Hukum, 1(1), 234-239, h.234-239, DOI: 10.22225/juinhum.1.1.2218.234-239 
penelitian hukum adalah serangkaian tata cara guna menemukan kaidah hukum tertentu, prinsip atau asas maupun pendapat-pendapat para ahli hukum untuk kemudian digunakan memecahkan masalah yang diteliti. ${ }^{9}$ Morris L. Cohen dan Kent C. Olson mengemukaakan "Legal research is essential component of legal pratice, it was the process of finding the law that governs an activity and materials". ${ }^{10}$ Pernyataan tersebut mengarah pada argumen penelitian adalah unsur utama dari tata laksana hukum secara praktis dalam hal penemuan aturan hukum yang mengatur kegiatan serta sarana dalam mengejaw antahkan atau menganalisis aturan tersebut. Penelitian hukum tersebut mengunakan metode penelitan normatif yang didasarkan pada sumber pustaka meliputi buku, literatur, dan lain sebagainya dengan dikaitkan pada peraturan perundang-undangan serta konsep/asas dan doktrin hukum. Penelitian ini bertitik tolak dari adanya kekosongan norma pada Pasal 1 angka 2 UUJN-Perubahan. Sebagai catatan, kekosongan norma adalah keadaan tiadanya norma hukum peraturan perundang-undangan yang mengatur hal konkret tertentu. Parameter kekosongan norma adalah tidak terdapatnya norma hukum dalam peraturan perundang-undangan yang mengatur satu atau beberapa peristiwa konkret tertentu (dalam arti luas); atau norma hukum tersebut telah ada namun tidak mampu menjangkau materi yang diperlukan pengaturannya/tidak lengkap (dalam arti sempit). ${ }^{11}$ Isu hukum yang diulas dalam penelitian ini termasuk kriteria kekosongan norma dalam arti sempit, karena pengaturannya telah ada sebagaimana ditentukan pada Pasal 1 angka 2 UUJNPerubahan namun terdapat ketidaklengkapan materi muatannya (tidak meliputi kedudukan Pejabat Sementara Notaris guna menjalankan jabatan Notaris yang diberhentikan sementara). Jenis pendekatan yang dipergunakan adalah pendekatan perundang-undangan serta pendekatan konseptual dengan sumber bahan hukum berupa bahan hukum primer, bahan hukum sekunder dan bahan hukum tersier. Teknik pengumpulan bahan hukum yang digunakan teknik sistem kartu dengan teknik analisisa bahan hukum berupa teknik deskriptif dan teknik konstruksi.

\section{Hasil dan Pembahasan}

\subsection{Ratio Legis Kedudukan Pejabat Sementara Notaris dalam Hal Notaris Diberhentikan Sementara dari Jabatannya}

Pasal 1 angka 1 UUJN-Perubahan menentukan "Notaris adalah pejabat umum yang berwenang untuk membuat akta autentik dan memiliki kewenangan lainnya sebagaimana dimaksud dalam Undang-Undang ini atau berdasarkan undang-undang lainnya." Pejabat umum merupakan orang yang menyandang jabatan tertentu dengan kewenangan yang melekat pada jabatannya itu yang bertalian dengan kepentingan masyarakat banyak, dalam konteks ini berarti pejabat yang mempunyai kewenangan dalam hal pembuatan akta autentik guna melayani kepentingan hukum masyarakat. ${ }^{12}$

\footnotetext{
${ }_{9}^{9}$ Marzuki, M. (2017). Penelitian Hukum. Edisi Revisi. Jakarta: Kencana. h.35.

${ }^{10}$ Adjie, H., Loc.cit.

${ }^{11}$ Diantha, I. M. P., \& SH, M. (2016). Metodologi Penelitian Hukum Normatif dalam Justifikasi Teori Hukum. Jakarta: Kencana Prenada Media Group. h.120.

12 Adjie, H., Op.cit, h.13.
} 
Kualifikasi Notaris sebagai pejabat umum di Indonesia tidaklah berdiri sendiri, dalam arti Notaris bukanlah satu-satunya pejabat umum, sebagaimana telah dikemukakan dalam uraian sebelumnya terdapat pula pejabat umum lainnya. ${ }^{13}$

Pembuatan akta autentik oleh atau di hadapan Notaris merupakan esensi dari prinsip melayani kepentingan masyarakat sebagaimana dimaksud di atas. Dalam hal ini, akta Notaris menjamin kepastian hukum atas hak dan kewajiban pihak atau para pihak yang berhubungan dengan tindakan hukum atau peristiwa hukum yang termaktub dalam akta Notaris yang bersangkutan. Akta Notaris mempunyai daya bukti yang sempurna yang meliputi daya bukti lahiriah, daya bukti formil, dan daya bukti materiil. Hal inilah yang menjadi dasar jaminan kepastian hukum atas akta Notaris, bahwa para pihak, ahli warisnya, atau pihak lain yang memperoleh hak daripadanya harus menerima segala sesuatu yang termuat pada akta Notaris itu sebagai sesuatu yang benar baik mengenai bentuknya, kepastian waktu pembuatan akta, kepastian pihak yang menandatangani akta, dan kepastian substansi tersebut. Pihak yang mendalilkan bahwa akta tersebut tidak benar harus membuktikannya (tegenbewijs). ${ }^{14}$

Berangkat dari hal-hal tersebut, maka orang-orang yang akan menduduki jabatan Notaris wajib memiliki spirit melayani masyarakat. Oleh karenanya, Notaris merupakan suatu jabatan umum dengan ciri-ciri sebagai berikut:

a. Merupakan suatu jabatan

UUJN jo. UUJN-Perubahan adalah penyatuan hukum jabatan Notaris di Indonesia, dalam arti aturan tersebut merupakan peraturan pokok yang menentukan mengenai jabatan Notaris di Indonesia oleh karenanya segala aspek yang berkenaan dengan Notaris harus berdasar pada UUJN jo UUJNPerubahan.

Jabatan Notaris adalah lingkungan pekerjaan tetap dengan sifat berkelanjutan yang diciptakan oleh negara dengan tujuan dan fungsi tertentu yang diejawantahkan melalui kewenangan yang melekat pada jabatan Notaris itu.

b. Notaris memiliki kewenangan atas hal-hal tertentu

Setiap kewenangan yang diberikan pada suatu jabatan baik secara atribusi, delegasi maupun mandat haruslah berdasarkan aturan yang berlaku. Sebagaimana telah dikemukakan pada uraian sebelumnya bahwa kewenangan merupakan kekuasaan yang sah, dengan demikian urgensi aturan yang mengatur kewenangan sebagaimana dimaksud di atas ditujukan sebagai limitasi agar suatu jabatan dapat berjalan sebagaimana mestinya dan tidak berbenturan dengan kewenangan pada jabatan lainnya. Oleh karenanya dalam hal Notaris melakukan suatu tindakan di luar kewenangannnya maka hal itu merupakan bentuk perbuatan melanggar kewenangan. Kewenangan Notaris secara limitatif diatur dalam Pasal 15 UUJN-Perubahan.

c. Pengangkatan dan pemberhentiannya dilakukan oleh pemerintah Pasal 2 UUJN menentukan bahwa "Notaris diangkat dan diberhentikan oleh pemerintah," dalam hal ini "Menteri yang membidangi urusan pemerintahan

${ }_{13}$ Ibid.

${ }^{14}$ Akhmad, S. N. (2019). Kekuatan Akta Autentik Yang Dibuat Oleh Notaris Untuk Pembuktian Terhadap Tindak Pidana Pemalsuan. Jurnal Hukum dan Kenotariatan, 3(1), 84-99, h.95 DOI: 10.33474/hukeno.v3i1.1921 
dibidang hukum" (Pasal 1 angka 14 UUJN-Perubahan). Kendati secara administratif diangkat dan diberhentikan oleh pemerintah," hal itu bukan bermakna terdapat garis perintah dengan hubungan atasan dan bawahan antara pemerintah dan Notaris. Pada dasarnya Notaris diangkat dan diberhentikan oleh negara, Menteri hanya sebagai representasi dari negara guna pemenuhan aspek formal dalam penerbitan keputusan tata usaha negara mengenai pengangkatan dan pemberhentian Notaris itu.

d. Tidak mendapatkan imbal jasa dalam bentuk gaji atau pensiunan dari pemerintah

Sebagaimana telah dikemukakan di atas bahwa Notaris bukan merupakan bawahan dari pemerintah, dalam hal ini Notaris melaksanakan sebagian kekuasaan negara dalam rumpun hukum perdata yang tidak terkualifikasi rumpun eksekutif, legislatif, maupun yudikatif sebagaimana ajaran Teori Trias Politica yang dianut oleh negara Indonesia. Dengan demikian Notaris tidak mendapatkan gaji maupun tunjangan pensiun atau imbal jasa dalam bentuk lainnya dari pemerintah. Notaris dalam menjalankan tugas jabatannya berhak mendapat honorarium dari para pengguna jasanya.

e. Akuntabilitas atas pelaksannan tugas jabatannya

Akuntabilitas dalam hal ini dimaksudkan sebagai prinsip pelaksanaan tugas jabatan Notaris yang dapat diaudit oleh negara maupun masyarakat selaku pengguna jasanya. Dalam hal akuntabilitas terhadap negara diejawantahkan melalui pemeriksaan rutin terhadap Notaris maupun protokol Notaris yang ada dalam penyimpanan Notaris oleh Majelis Pengawas Daerah. Akuntabilitas Notaris terhadap mesyarakat selaku pengguna jasa ditunjukkan melalui pertanggung jawaban perdata Notaris terhadap pihak atau para pihak yang dirugikan sehubungan dengan tindakan Notaris di luar kewenangannya. ${ }^{15}$

Notaris merupakan jabatan yang dikehendaki kehadirannya oleh negara guna membantu memberikan pelayanan masyarakat umum dalam hal pembuatan akta autentik.16 Guna hal tersebut, negara mengatribusikan kewenangan kepada jabatan Notaris sebagaimana ditentukan dalam UUJN-Perubahan dan undang-undang lainya, sedangkan orang yang menyandang jabatan tersebut disebut sebagai pejabat. Bahwa rumusan norma Pasal 1 angka 1 UUJN-Perubahan sebagaimana telah diuraikan di atas ditujukan kepada orang yang menyandang jabatan Notaris (pejabat). Jabatan berarti lingkungan pekerjaan dalam suatu organisasi baik organisasi kenegaraan maupun organisasi privat. Makna jabatan sebagaimana tersebut adalah makna jabatan yang umum yaitu untuk setiap lingkungan pekerjaan yang dengan sengaja dibentuk guna kepentingan sekelompok orang yang dapat disesuaikan baik dengan cara diubah, ditambah maupun dibubarkan dalam suatu waktu tertentu dengan mempertimbangkan kebutuhan dan kondisi yang ada. Jabatan dalam artian ambt adalah fungsi tugas dan bidang pekerjaan pada organisasi kenegaraan maupun alat perlengkapan yang terkait. Menurut E. Utrecht, jabatan (ambt) merupakan lingkukan pekerjaan tetap yang dibentuk serta dilangsungkan untuk kepentingan publik. ${ }^{17}$

${ }^{15}$ Adjie, H., Op.cit, h.15.

16 Swastika, W. A. (2016). Politik Hukum Pembentukan Majelis Kehormatan Notaris. Lex Renaissance, 1(2), 182-200, h.188, DOI: 10.20885/JLR.vol1.iss2.art4

17 Ridwan, R. (2013). Kedudukan Hukum Pegawai Tidak Tetap di Lingkungan Instansi Pemerintah. Civil Service Journal, 7(2), 54-65, h.59. 
Kemudian daripada itu, adapun yang diartikan dengan lingkungan pekerjaan tetap yakni bidang pekerjaan yang dikualifikasikan dengan tepat, tetap, serta teliti dan tidak dapat diubah dengan serta merta begitu saja.

Jabatan adalah subjek hukum yaitu penyandang kewajiban serta hak. Dalam perspektif Hukum Tata Negara, kewenangan sebagai bentuk kekuasaan yang sah berdasar hukum tidak dapat diserahkan begitu saja kepada pejabat (orang yang menduduki jabatan), namun diberikan kepada jabatannya. Sebagai suatu subjek hukum berupa badan hukum, dengan demikian jabatan tersebut dapat memberikan jaminan atas keberlangsungan kewajiban dan hak. Pejabat dapat berganti seiring berjalannya waktu sedangkan jabatan akan tetap ada sepanjang dibutuhkan. Misalnya jabatan kepala pemerintahan (Perdana Menteri atau Presiden) merupakan jabatan yang bersifat berkesinambungan, tetap ada selama dibutuhkan guna memimpin jalannya pemerintahan di suatu negara. Jabatan-jabatan tersebut disandang oleh pejabat yang diangkat untuk kurun waktu tertentu guna menjalankan jabatan itu. ${ }^{18}$

Jabatan merupakan bidang tugas atau pekerjaan yang dimaksudkan dibentuk oleh aturan hukum guna kepentingan dan fungsi tertentu serta memiliki sifat berkelanjutan. Jabatan adalah subjek hukum yang dapat menyandang kewajiban dan hak. Guna berjalannya suatu jabatan sebagaimana mestinya maka jabatan tersebut harus diisi oleh orang, orang tersebut dinamakan pejabat. Jabatan yang tidak diisi oleh pejabat maka jabatan itu tidak dapat berlangsung sebagaimana mestinya. ${ }^{19}$

Berdasarkan kedudukan tersebut, bahwa sekalipun Notaris (pejabat) tidak dapat lagi menjalankan tugas jabatannya, jabatannya akan tetap ada. Dalam hal ini beberapa hal yang dapat mengakibatkan Notaris tidak dapat lagi melaksanakan tugas jabatannya diantaranya:

1. Diberhentikannya Notaris yang bersangkutan dengan hormat atau berhenti demi hukum;

2. Diberhentikannya Notaris yang bersangkutan untuk jangka waktu tertentu atau diberhentikan sementara;

3. Cuti;

4. Diberhentikannya Notaris yang bersangkutan dengan tidak hormat dari jabatannya.

Adapun alasan-alasan yang dapat mengakibatkan Notaris berhenti demi hukum atau diberhentikan dengan hormat dari jabatannya berdasarkan Pasal 8 ayat (1) UUJN adalah segai berikut:

"a. Meninggal dunia;

b. Telah berumur 65 (enam puluh lima) tahun (ketentuan umur ini dapat diperpanjang sampai berumur 67 (enam puluh tujuh tahun) dengan

${ }^{18}$ Hakim, L. (2011). Kewenangan Organ Negara dalam Penyelenggaraan Pemerintahan. Jurnal Konstitusi, 4(1), 103-130, h.111.

${ }_{19}$ Maradesa, K. R. (2014). Kewenangan Serta Tanggung Jawab Hukum Atas Pembuatan Akta Otentik Oleh Notaris Berdasarkan Undang-undang Tentang Jabatan Notaris. Lex Privatum, 2(3), 138-146, h.138. 
mempertimbangkan kesehatan yang bersangkutan berdasarkan ketentuan Pasal 8 ayat (2) UUJN);

c. Permintaan sendiri;

d. Tidak mampu secara rohani dan/atau jasmani untuk melaksanakan tugas jabatan Notaris secara terus-menerus lebih dari 3 (tiga) tahun; atau

e. Merangkap jabatan sebagaimana dimaksud dalam Pasal 3 huruf g (pegawai negeri, pejabat negara, advokat, atau jabatan lain yang oleh undang-undang dilarang untuk dirangkap dengan jabatan Notaris)."

Alasan-alasan yang mengakibatkan Notaris diberhentikan untuk jangka waktu tertentu (sementara) sebagaimana ditentukan Pasal 9 ayat (1) UUJN-Perubahan adalah meliputi:

“a. Dalam proses pailit atau penundaan kewajiban pembayaran utang;

b. Berada di bawah pengampuan;

c. Melakukan perbuatan tercela;

d. Melakukan pelanggaran terhadap kewajiban dan larangan jabatan serta kode etik Notaris; atau

e. Sedang menjalani masa penahanan."

Dalam hal Notaris cuti disebabkan karena Notaris tersebut "diangkat menjadi pejabat negara atau berhalangan sementara" (vide Pasal 25 ayat (2) UUJN) Cuti tersebut "dapat diambil setelah Notaris menjalankan jabatannya selama 2 (dua) tahun dan dapat diambil setiap tahun atau sekaligus beberapa tahun dengan ketentuan setiap pengambilan cuti paling lama 5 (lima) tahun sudah termasuk perpanjangannya dan selama masa jabatan Notaris waktu cuti keseluruhan paling lama 12 (dua belas) tahun" (vide Pasal 26 ayat (1), (2) dan (3) UUJN).

Mengenai hal-hal yang dapat menyebabkan Notaris diberhentikan dengan tidak hormat dari jabatannya berdasarkan Pasal 12 UUJN adalah sebagai berikut:

“a. Dinyatakan pailit berdasarkan putusan pengadilan yang telah memperoleh kekuatan hukum tetap;

b. Berada di bawah pengampuan secara terus-menerus lebih dari 3 (tiga) tahun;

c. Melakukan perbuatan yang merendahkan kehormatan dan martabat jabatan Notaris; atau

d. Melakukan pelanggaran berat terhadap kewajiban dan larangan jabatan."

Kemudian dalam Pasal 13 UUJN, latar belakang pemberhentian dengan tidak hormat sebagaimana dimaksud di atas ditambahkan sebagai berikut:

“Dijatuhi pidana penjara berdasarkan putusan pengadilan yang telah memperoleh kekuatan hukum tetap karena melakukan tindak pidana yang diancam dengan pidana penjara 5 (lima) tahun atau lebih (vide Pasal 13 UUJN)."

Khusus mengenai Notaris (pejabat) yang diberhentikan sementara dari jabatannya, maka jabatan yang bersangkutan dapat dijabat sementara oleh Pejabat Sementara Notaris. Hal ini mengacu pada ketentuan Pasal 80 UUJN sebagai berikut:

“(1) Selama Notaris diberhentikan sementara dari jabatannya, Majelis Pengawas Pusat mengusulkan Pejabat Sementara Notaris kepada Menteri. 
(2) Menteri menunjuk Notaris yang akan menerima Protokol Notaris dari Notaris yang diberhentikan sementara."

Ketentuan tersebut berarti bahwa dalam hal Notaris diberhentikan sementara berdasarkan hal-hal sebagaimana ditentukan Pasal 9 ayat (1) UUJN-Perubahan dan sanksi administratifnya telah dijatuhkan oleh Majelis Pengawas Pusat serta tidak diajukan gugatan ke pengadilan tata usaha negara (mengingat kedudukan Majelis Pengawas Notaris merupakan badan atau jabatan tata usaha negara yang memiliki kewenangan menerbitkan ketetapan atau keputusan tata usaha negara sehubungan dengan supervisi, pemeriksaan atau pengenaan sanksi administratif terhadap Notaris) maka Majelis Pengawas Pusat berkewajiban merekomendasikan Pejabat Sementara Notaris kepada Menteri guna menjalankan jabatan dari Notaris tersebut untuk sementara waktu. Dalam hal Menteri menyetujui usul tersebut, Pejabat Sementara Notaris yang bersangkutan wajib mengambil dan diambil sumpah/janji jabatannya di hadapan Menteri atau Kepala Kantor Wilayah Kementerian Hukum dan Hak Asasi Manusia atau Kepala Divisi Pelayanan Hukum Kantor Wilayah Kementerian Hukum dan Hak Asasi Manusia dalam hal Kepala Kantor Wilayah berhalangan.

Atas hal tersebut dapat ditinjau berdasarkan Teori Kemanfaatan Hukum (Utilitarianisme) oleh Jeremy Bentham. Kemanfaatan adalah anasir penting dalam suatu tujuan hukum, tentang tujuan hukum pada awalnya diselidiki yang dimaksud dengan tujuannya itu dan yang memiliki tujuan tersebut hanya pada manusia, namun hukum bukan merupakan tujuan manusia, hukum hanya suatu instrumen guna mencapai tujuan yang dicita-citakan dalam kehidupan bermasyarakat serta bernegara. Tujuan hukum tampak dari fungsinya guna melindungi kepentingan manusia pada umumnya, hukum memiliki tujuan pokok yang akan dicapai. ${ }^{20}$ Teori utilitarianisme berpandangan hukum haruslah menjamin kebahagian bagi manusia dengan kuantitas yang sebesar-besarnya. Pada prinsipnya tujuan hukum menurut teori ini adalah kegunaannya untuk menghasilkan kebahagiaan dalam jumlah yang paling besar.

Kontra narasi atas teori ini dikemukakan oleh Utrecht yang mengemukakan tiga hal, bahwa teori utilitarianisme tersebut:

1. Tidak memberikan ruang guna memperhitungkan seadil-adilnya aspek-aspek yang bersifat konkret.

2. Hanya mengutamakan aspek-aspek yang memiliki nilai kegunaan yang tinggi oleh karenanya materinya bersifat umum.

3. Mengutamakan kepentingan individu atau bersifat individualistis dan tidak memberikan ruang pada rasa keadilan hukum pada seseorang. ${ }^{21}$

Berdasarkan uraian teori tersebut dan dikaitkan dengan narasi yang telah dikemukakan dalam sub bab ini berkenaan dengan eksistensi Pejabat Sementara Notaris yang ditujukan guna menjalankan jabatan Notaris yang diberhentikan

${ }^{20}$ Ridwansyah, M. (2016). Mewujudkan Keadilan, Kepastian dan Kemanfaatan Hukum dalam Qanun Bendera dan Lambang Aceh. Jurnal Konstitusi, 13(2), 278-298, h.13, DOI: $10.31078 / \mathrm{jk} 1323$

${ }^{21}$ Hidin, M., \& Jabar, A. (2020). ImplementasiPeraturan Daerah (Perda) Nomor 12 Tahun 2008 tentang Retribusi Parkir Kendaraan Kabupaten Jember terhadap Sistem Retribusi Parkir Berlangganan. Rechtenstudent, 1(2), 140-153, h.144, DOI: 10.35719/rch.v1i2.22 
sementara dari jabatannya, bahwa ratio legis kedudukan Pejabat Sementara Notaris sebagaimana dimaksud adalah guna mempertahankan keberlangsungan jabatan Notaris itu sendiri. Notaris (pejabat) tidak dapat melaksanakan tugas jabatannya untuk sementara waktu karena diberhentikan sementara, namun jabatan Notaris harus tetap ada karena merupakan lingkungan pekerjaan tetap dengan tujuan melayani masyarakat berdasarkan kewenangannya. Hal inilah yang merupakan kemanfaatan dari eksistensi Pejabat Sementara Notaris dalam kedudukannya sebagaimana dimaksud. Walaupun kedudukan Notaris (pejabat) yang diberhentikan sementara berarti bahwa yang bersangkutan dijatuhi hukuman yang mengakibatkan pejabat itu tidak lagi mempunyai kewenangan apapun (tidak dapat melaksanakan tugas jabatan berdasarkan kewenangannya) sehingga tidak tepat jika pejabat yang telah tidak mempunyai kewenangan apapun kendati keadaan tersebut untuk jangka waktu tertentu (sementara) kewenangannya itu dilaksanakan oleh pejabat lain. Namun dalam teori utilitarianisme, hal ini bukanlah pokok persoalan, karena yang terpenting adalah kemanfaatan bagi sebanyak-banyaknya orang (masyarakat) guna menjamin kepastian hukum atas perbuatan hukumnya dalam lalu lintas hukum perdata yang dituangkan dalam akta Notaris.

Urgensi pembahasan mengenai ratio legis kedudukan Pejabat Sementara Notaris dalam hal Notaris diberhentikan sementara dari jabatannya adalah guna mengelaborasi materi muatan Pasal 1 angka 2 UUJN-Perubahan yang dalam perspektif ius constitutum hanya melingkupi kedudukan Pejabat Sementara Notaris guna menjalankan jabatan Notaris yang meninggal dunia. Padahal sebagaimana diuraikan di atas bahwa Notaris (jabatan) merupakan lingkungan pekerjaan tetap yang bersifat berkesinambungan yang harus tetap berjalan sekalipun pejabatnya tidak lagi memiliki kewenangan menjalankan tugas jabatannya tersebut. Berpokok pangkal dari hal inilah, maka relevan jika lingkup pengaturan kedudukan Pejabat Sementara Notaris diperluas hingga meliputi Notaris yang diberhentikan sementara dari jabatannya dengan didasarkan pada Teori Kemanfaatan Hukum tersebut di atas.

\subsection{Reformulasi Pengaturan atas Kedudukan Pejabat Sementara Notaris dalam hal Notaris Diberhentikan Sementara dari Jabatannya}

Sebagaimana yang telah diuraikan pada pembahasan sebelumnya bahwa pemberhentian sementara Notaris diikuti usul penunjukan Pejabat Sementara Notaris guna melaksanakan jabatan Notaris pada saat Notaris tersebut diberhentikan sementara dari jabatannya sesuai yang ditentukan Pasal 80 ayat (1) UUJN bahwa: "Selama Notaris diberhentikan sementara dari jabatannya, Majelis Pengawas Pusat mengusulkan Pejabat Sementara Notaris kepada Menteri."

Adapun maksud Pejabat Sementara Notaris ditentukan Pasal 1 angka 2 UUJNPerubahan bahwa "Pejabat Sementara Notaris adalah seorang yang untuk sementara menjabat sebagai Notaris untuk menjalankan jabatan dari Notaris yang meninggal dunia." Ketentuan normatif ini secara limitatif merumuskan kedudukan Pejabat Sementara Notaris guna melaksanakan jabatan Notaris yang meninggal dunia, dan bukan untuk Notaris yang diberhentikan untuk jangka waktu tertentu (sementara) dari jabatannya. 
Masa jabatan Pejabat Sementara Notaris adalah maksimal untuk waktu selama 60 (enam puluh) hari, hal ini dapat dicermati dari Pasal 35 ayat (4) UUJN-Perubahan bahwa "Pejabat Sementara Notaris dari Notaris yang meninggal dunia kepada Majelis Pengawas Daerah paling lama 60 (enam puluh) hari terhitung sejak tanggal Notaris meninggal dunia (garis bawah dari penulis)." Dalam hal ini terhitung sejak tanggal Pejabat Sementara Notaris mengangkat dan diangkat sumpah/janji jabatan menurut agamanya yang sebelumnya didahului dengan penunjukan guna menduduki jabatan tersebut hingga maksimal untuk waktu selama 60 (enam puluh) hari, waktu tersebut dihitung sejak Notaris yang digantikan meninggal dunia, Pejabat Sementara Notaris yang bersangkutan berwenang menjalankan tugas jabatan Notaris yang meninggal dunia itu sekaligus bertindak sebagai pemegang protokol Notaris. Setelah lewatnya waktu sebagaimana dimaksud di atas, Pejabat Sementara Notaris tersebut demi hukum berhenti menjabat dan wajib menyerahkan protokol Notaris kepada Majelis Pengawas Daerah.

Berkaitan dengan uraian di atas, sebagai catatan bahwa jangka waktu pemberhentian sementara Notaris dari jabatannya adalah 3-6 (tiga sampai enam) bulan. Hal ini mengacu pada kewenangan Majelis Pengawas Wilayah serta kewenangan Majelis Pengawas Pusat sehubungan dengan sanksi tersebut sebagaimana ditentukan dalam Pasal 73 ayat (1) huruf f angka 1) UUJN-Perubahan jo Pasal 77 huruf c UUJN sebagai berikut:

a. Pasal 73 ayat (1) huruf $\mathrm{f}$ angka 1) UUJN-Perubahan

“Majelis Pengawas Wilayah berwenang: mengusulkan pemberian sanksi terhadap Notaris kepada Majelis Pengawas Pusat berupa pemberhentian sementara 3 (tiga) bulan sampai dengan 6 (enam) bulan (garis bawah dari penulis)."

b. Pasal 77 huruf c UUJN

"Majelis Pengawas Pusat berwenang: menjatuhkan sanksi pemberhentian sementara."

Termin tersebut di atas dipertegas dalam ketentuan Pasal 7 ayat (1) Peraturan Hukum dan Hak Asasi Manusia Nomor 61 tahun 2016 tentang Tata Cara Penjatuhan Sanksi Administratif terhadap Notaris, sebagai berikut "Pemberhentian sementara sebagaimana dimaksud pada Pasal 6 ayat (1) dijatuhkan untuk jangka waktu 3 (tiga) bulan sampai dengan 6 (enam) bulan."

Beranjak pada narasi tersebut di atas, bahwa terdapat kekosongan norma dalam Pasal 1 angka 2 UUJN-Perubahan yang tidak merumuskan kedudukan Pejabat Sementara Notaris guna menjalankan tugas jabatan dari Notaris yang diberhentikan sementara dari jabatannya. Atas hal ini diperlukan pembentukan norma guna mengisi kekosongan norma (leemten van normen) dalam Pasal 1 angka 2 UUJN-Perubahan tersebut berdasarkan teori pembentukan peraturan perundang-undangan dari L. Fuller. Norma baru itu berkedudukan sebagai hukum yang dikehendaki dan akan berlaku kemudian (ius constituendum).

Menurut L. Fuller, dalam Teori Pembentukan Peraturan Perundang-undangan, suatu peraturan perundang-undangan yang berkualitas haruslah mengesampingkan 8 aspek yang mengakibatkan ketidakpastian hukum, meliputi:

1. Ketidakjelasan maksud peraturan perundang-undangan tersebut; 
2. Tidak adanya pengakuan dari masyarakat atas peraturan perundangundangan tersebut dalam bentuk ketaatan masyarakat yang;

3. Pengunaan asas non-legalitas (retroaktif) yang tidak tepat penggunaannya;

4. Ketidak lengkap substansi peraturan perundang-undangan tersebut;

5. Inkonsistensi substansi peraturan perundang-undangan yang bersangkutan baik dalam satu kesatuan peraturan perundang-undangan maupun dengan peraturan perundang-undangan lainnya;

6. Memuat ketentuan-ketentuan yang tidak atau kurang dapat dilaksanakan;

7. Perubahan atas peraturan perundang-undangan tersebut dilakukan secara konstan dalam waktu yang berdekatan;

8. Tidak terdapat kesesuaian antara materi muatan yang diatur dalam peraturan perundang-undangan itu dengan penegakannya di lapangan. ${ }^{22}$

Ketidak lengkapan peraturan perundang-undangan sebagaimana tersebut dalam poin 4 tersebut di atas berarti materi muatan peraturan perundang-undangan itu tidak menentukan secara menyeluruh atas suatu peristiwa konkret tertentu. Oleh karenanya terdapat kekosongan norma yang mengakibatkan ketidak pastian hukum.

Kepastian hukum adalah anasir dalam perspektif normatif dan tidak meliputi dimensi sosiologis. Kepastian hukum dalam tataran normatif adalah pada saat suatu peraturan dibentuk berdasarkan peristiwa konkret tertentu yang bersifat jelas serta logis. Jelas dalam hal ini berarti peraturan tersebut tidak menimbulkan multiinterpretasi, sedangkan logis berarti peraturan tersebut menjadi suatu rangkaian yang harmonis dalam sistem norma hukum secara garis besar sehingga tidak menimbulkan disharmoni norma. Disharmoni norma yang disebabkan oleh ketidak pastian suatu peraturan perundang-undangan dapat berupa reduksi, distorsi, maupun kontestasi norma. ${ }^{23}$

Pada hakekatnya suatu peraturan perundang-undangan seringkali dibentuk setelah suatu peristiwa konkret tertentu terjadi. Hal ini mengakibatkan peraturan perundangundangan itu tertinggal oleh dinamika masyarakat yang begitu pesat. Bagir Manan mengemukakan bahwa peraturan perundang-undangan demikian bersifat statis (tidak fleksibel mengikuti perkembangan masyarakat) serta tidak pernah lengkap dalam mengisi kebutuhan hukum masyarakat sehingga menimbulkan kekosongan hukum, baik diartikan sebagai kekosongan peraturan perundang-undangan (dalam arti luas) maupun kekosongan norma (dalam arti sempit). ${ }^{24}$

Kekosongan peraturan perundang-undangan merupakan keadaan kosong atas suatu peraturan perundang-undangan guna mengatur peristiwa konkrit (tertentu). Dalam hal ini pengaturan atas peristiwa tersebut sama sekali tidak ada. Sedangkan kekosongan norma adalah ketiadaan suatu atruan hukum terhadap satu atau lebih

22 Coubrey, H. M., dan White, N. D. (2012). Texbook on Jurispridence. Edisi Kelima. London: Blackstone Press Limited. h.161.

${ }^{23}$ Julyano, M., \& Sulistyawan, A. Y. (2019). Pemahaman Terhadap Asas Kepastian Hukum Melalui Konstruksi Penalaran Positivisme Hukum. Jurnal Crepido, 1(1), 13-22, h.15, DOI: 10.14710/crepido.1.1.13-22

${ }^{24}$ Natabaya, H. A.S. (2017). Sistem Peraturan Perdundang-Undangan Inonesia. Jakarta: Konstitusi Press dan Tatanusa. h.4. 
peristiwa yang pengaturan terhadap peristiwa yang berkaitan telah ada sebelumnya. Perbedaan antara kedua anasir tersebut adalah terletak pada luasnya cakupan peraturan atas peristiwa konkrit.

Pasal 1 angka 2 UUJN-Perubahan merupakan bentuk kekosongan norma, dikaitkan dengan Teori Pembentukan Peraturan Perundang-Undangan dari L. Fuller tersebut di atas, maka diperlukan pengaturan yang lebih komprehensif dengan mengatur perihal kedudukan Pejabat Sementara Notaris, bukan saja untuk jangka waktu tertentu (sementara) menjalankan tugas jabatan Notaris yang meninggal dunia, namun lebih luas lagi yakni melingkupi pula Notaris yang diberhentikan sementara dari jabatannya sehingga sesuai dengan rumusan norma Pasal 88 ayat (1) UUJN. Sebagai catatan sebelum berlakunya UUJN-Perubahan, ketentuan mengenai definisi Pejabat Sementara Notaris ditentukan pada Pasal 1 angka 2 UUJN “Pejabat Sementara Notaris adalah seseorang yang untuk sementara menjabat sebagai Notaris untuk menjalankan jabatan Notaris yang meninggal dunia, diberhentikan, atau diberhentikan sementara." Norma ini tampak lengkap karena meliputi pula kedudukan Pejabat Sementara Notaris bagi Notaris yang diberhentikan atau diberhentikan untuk jangka waktu tertentu (sementara).

Berdasarkan seluruh uraian sebagaimana dimaksud di atas, setelah dibentuknya norma baru dengan merevisi ketentuan Pasal 1 angka 2 UUJN-Perubahan selanjutnya akan berbunyi: "Pejabat Sementara Notaris adalah seorang yang untuk sementara menjabat sebagai Notaris untuk menjalankan jabatan dari Notaris yang meninggal dunia atau diberhentikan sementara dari jabatannya." Dengan demikian kedudukan Pejabat Sementara Notaris dalam hal Notaris diberhentikan sementara dari jabatannya menjadi tepat dan sesuai dengan norma Pasal 80 ayat (1) UUJN.

Relevansi sub bahasan ini adalah terkait dengan solusi atas permasalahan normatif kekosongan norma dalam Pasal 1 angka 2 UUJN-Perubahan sebagaimana isu hukum yang diulas dalam penelitian ini. Sebagaimana uraian di atas, atas kekosongan norma tersebut diperlukan pembentukan norma baru. Pembentukan norma tersebut terkualifikasi dalam penciptaan hukum. Penciptaan hukum (rechtsschepping) berbeda dengan penemuan hukum (rechtsvinding). Penciptaan hukum menunjuk pada situasi dimana hakim tidak boleh menolak suatu perkara dengan alasan normanya tidak ada baik dalam hukum tertulis maupun tidak tertulis. Dalam hal ini, hakim menciptakan norma hukum baru untuk perkara hukum khusus tersebut sehingga kekuatan hukumnya hanya berlaku pada pihak-pihak yang berperkara semata. Sedangkan penemuan hukum berarti mencari dan menemukan kaidah atau norma hukum yang sebelumnya sudah ada baik dalam hukum tertulis maupun hukum tidak tertulis. ${ }^{25}$

Problematik yang berhubungan dengan penciptaan hukum pada umumnya dipusatkan di sekitar hakim dan pembentuk undang-undang. Khusus pada pembentuk undang-undang, hasil penciptaan hukum tersebut merupakan hukum (tertulis) karena dituangkan dalam bentuk undang-undang (dalam arti sempit) maupun peraturan perundang-undangan (dalam arti luas) dan sekaligus merupakan sumber hukum yang mempunyai kekuatan hukum mengikat. Pembentukan norma

${ }^{25}$ Diantha, I. M. P., \& SH, M. Op.cit. h.83. 
atas permasalahan normatif kekosongan norma dalam Pasal 1 angka 2 UUJNPerubahan merupakan tugas dan kewenangan pembentuk undang-undang.

\section{Kesimpulan}

Beranjak pada pembahasan penelitian ini, maka kesimpulan yang didapat sebagai berikut, Ratio legis kedudukan Pejabat Sementara Notaris dalam hal Notaris diberhentikan sementara dari jabatannya adalah untuk mempertahankan keberlangsungan jabatan Notaris itu sendiri. Berdasarkan Teori Kemanfaatan Hukum (Utilitarianisme), meskipun Notaris (pejabat) tidak dapat melaksanakan tugas jabatannya untuk sementara waktu karena diberhentikan sementara, namun jabatan Notaris harus tetap ada karena merupakan lingkungan pekerjaan tetap dengan tujuan memberikan pelayanan atas kepentingan masyarakat umum yang memerlukan alat bukti tertulis (akta autentik) atas perbuatan hukum pihak atau para pihak yang bersangkutan dalam lalu lintas hukum privat. Reformulasi pengaturan atas kedudukan Pejabat Sementara Notaris dalam hal Notaris diberhentikan sementara dari jabatannya berdasarkan Teori Pembentukan Peraturan Perundang-Undangan dari L. Fuller adalah dengan pembentukan norma yang merevisi ketentuan Pasal 1 angka 2 UUJN-Perubahan sehingga kemudian kedudukan Pejabat Sementara Notaris bukan saja untuk jangka waktu tertentu (sementara) menjalankan tugas jabatan Notaris yang meninggal dunia, namun lebih luas lagi yakni melingkupi pula Notaris yang diberhentikan sementara dari jabatannya.

\section{Daftar Pustaka}

\section{$\underline{\text { Buku }}$}

Adjie, H. (2018). Hukum Notaris Indonesia (Tafsir Tematik Terhadap UU No. 30 Tahun 2004 Tentang Jabatan Notaris). Bandung: Refika Aditama.

Coubrey, H. M., dan White, N. D. (2012). Texbook on Jurispridence. Edisi Kelima. London: Blackstone Press Limited.

Diantha, I. M. P., \& SH, M. (2016). Metodologi Penelitian Hukum Normatif dalam Justifikasi Teori Hukum. Jakarta: Kencana Prenada Media Group.

Marzuki, M. (2017). Penelitian Hukum. Edisi Revisi. Jakarta: Kencana.

Natabaya, H. A. S. (2017). Sistem Peraturan Perdundang-Undangan Inonesia. Jakarta: Konstitusi Press dan Tatanusa.

\section{Jurnal}

Akhmad, S. N. (2019). Kekuatan Akta Autentik Yang Dibuat Oleh Notaris Untuk Pembuktian Terhadap Tindak Pidana Pemalsuan. Jurnal Hukum dan Kenotariatan, 3(1), 84-99, DOI: 10.33474/hukeno.v3i1.1921

Erwinsyahbana, T. (2018). Kewenangan dan Tanggung Jawab Notaris Pengganti setelah Pelaksanaan Tugas dan Jabatan Berakhir. Lentera Hukum, 5(2), 323-340, DOI: 10.19184/ ejlh.v5i2.7339

Hakim, L. (2011). Kewenangan Organ Negara dalam Penyelenggaraan Pemerintahan. Jurnal Konstitusi, 4(1), 103-130. 
Hidin, M., \& Jabar, A. (2020). Implementasi Peraturan Daerah (Perda) Nomor 12 Tahun 2008 tentang Retribusi Parkir Kendaraan Kabupaten Jember terhadap Sistem Retribusi Parkir Berlangganan. Rechtenstudent, 1(2), 140-153, DOI: 10.35719/rch.v1i2.22

Julyano, M., \& Sulistyawan, A. Y. (2019). Pemahaman Terhadap Asas Kepastian Hukum Melalui Konstruksi Penalaran Positivisme Hukum. Jurnal Crepido, 1(1), 13-22, DOI: $10.14710 /$ crepido.1.1.13-22

Krisnayanti, N. N. C., Widiati, I. A. P., \& Astiti, N. G. K. S. (2020). Tanggung Jawab Notaris Pengganti dalam Hal Notaris yang Diganti Meninggal Dunia Sebelum Cuti Berakhir. Jurnal Interpratasi Hukum, 1(1), 234-239, DOI: 10.22225/juinhum.1.1.2218.234-239

Maradesa, K. R. (2014). Kewenangan Serta Tanggung Jawab Hukum Atas Pembuatan Akta Otentik Oleh Notaris Berdasarkan Undang-undang Tentang Jabatan Notaris. Lex Privatum, 2(3), 138-146.

Momuat, O. M. (2014). Alat Bukti Tulisan Dalam Pemeriksaan Perkara Perdata Di Pengadilan. Lex Privatum, 2(1). 134-143.

Pramono, D. (2015). Kekuatan Pembuktian Akta Yang Dibuat Oleh Notaris Selaku Pejabat Umum Menurut Hukum Acara Perdata Di Indonesia. Lex Jurnalica, 12(3), 248-258.

Ridwan, R. (2013). Kedudukan Hukum Pegawai Tidak Tetap di Lingkungan Instansi Pemerintah. Civil Service Journal, 7(2), 54-65.

Ridwansyah, M. (2016). Mewujudkan Keadilan, Kepastian dan Kemanfaatan Hukum dalam Qanun Bendera dan Lambang Aceh. Jurnal Konstitusi, 13(2), 278-298, DOI: $10.31078 / \mathrm{jk} 1323$

Sagama, S. (2016). Analisis Konsep Keadilan, Kepastian Hukum dan Kemanfaatan dalam Pengelolaan Lingkungan. Mazahib, 15(1), 20-41, DOI: 10.21093/mj.v15i1.590

Swastika, W. A. (2016). Politik Hukum Pembentukan Majelis Kehormatan Notaris. Lex Renaissance, 1(2), 182-200, DOI: 10.20885/JLR.vol1.iss2.art4

Tantri, W.K. (2020). Kewenangan PejabatSementara Notaris yang Membuat Akta Pertanahan Tidak dalam Kewenangannya Sebagai PPAT. Indonesian Notary, 2(4), 696-716.

\section{Peraturan Perundang-Undangan}

Undang-Undang Dasar Negara Republik Indonesia 1945.

Undang-Undang Nomor 30 Tahun 2004 Tentang Jabatan Notaris (Lembaran Negara Republik Indonesia Tahun 2004 Nomor 117, Tambahan Lembaran Negara Republik Indonesia Nomor 4432).

Undang-Undang Nomor 2 Tahun 2014 Tentang Perubahan atas Undang-Undang Nomor 30 Tahun 2004 Tentang Jabatan Notaris (Lembaran Negara Republik Indonesia Tahun 2014 Nomor 3, Tambahan Lembaran Negara Republik Indonesia Nomor 5491).

Peraturan Hukum dan Hak Asasi Manusia Nomor 61 tahun 2016 tentang Tata Cara Penjatuhan Sanksi Administratif Terhadap Notaris (Berita Negara Republik Indonesia Nomor 2128 Tahun 2016). 